\title{
Medvedemolpus gen.n. - a new genus of Eumolpinae (Coleoptera: Chrysomelidae) from Philippines
}

\author{
Medvedemolpus gen.n. - новый род Eumolpinae \\ (Coleoptera: Chrysomelidae) с Фимиппин
}

\begin{abstract}
A.G. Moseyko
А.Г. Мосейко

Zoological Institute of Russian Academy of Sciences, Universitetskaya nab., 1, St. Petersburg 199034, Russia.

Зоологический институт Российской академии наук, Университетская наб. 1, Санкт-Петербург 199034, Россия.

KEY WORDS: Chrysomelidae, Eumolpinae, Medvedemolpus, new genus, new species.

КЛЮЧЕВЫЕ СЛОВА: Chrysomelidae, Eumolpinae, Medvedemolpus, новый род, новые виды.
\end{abstract}

ABSTRACT. A new genus Medvedemolpus gen.n. (tribe Nodinini; section Typophorites) and four new species - M. quadripunctatus, M. quinquepunctatus, M. basilianus and M. bakeri spp.n., are described from Philippines.

РЕЗЮМЕ. С Филиппинских островов описывается новый род Medvedemolpus gen.n. (триба Nodinini; секция Туроphorites) и четыре новых вида - $M$. quadripunctatus, M. quinquepunctatus, M. basilianus и M. bakeri spp.n.

A tribe Nodinini is widely distributed in Oriental region. It is divided into five sections [Seeno \& Wilcox, 1982] by characters of shape of anterior margin of "propleurae" (lateral parts of prosternum), presence or absence of ocular grooves and type of the claws (appendiculate or bifid). All these characters in some species are sometimes of transitional form but so far they are the basis for the generic system of the tribe along with shape of antennae segments (flattened or not), teeth on femurs and in some cases body shape.

In the material collected by Baker in early XXth century and preserved in Smithsonian Institution I found 11 specimens belonging to undescribed genus from the section Typophorites and being closely related to the genus Mouhotina Lefèvre, 1885, described for species from Cambodia and to the Neotropical genus Typophorus Chevrolat in Dejean, 1836. The study of this material has showed that it is divided into several geographical forms, differing as to body size, pattern of elytra (if present), shape of aedeagus and some other characters of terminalia. The degree of differences in shape of aedeagus allows to consider these forms as good species, but if in a future the transitional forms will be found, some described species can be considered as subspecies. An additional specimen was found in collection of Lev Medvedev (Moscow). The descriptions of the genus and 4 new species, a key to the species of
Medevedemolpus gen.n. and to the genera of Philippinese Nodinini are given below. Some forms with unknown males continue to remain undescribed.

DEPOSITARIES: USNM - National Museum of Natural History, Smithsonian Institution, Washington; ZISP - Zoological Institute of Russian Academy of Sciences, St. Petersburg; cLM - Lev Medvedev's collection, Moscow.

\section{Medvedemolpus gen.n.}

Type species - M. bakeri Moseyko, sp.n.

DESCRIPTION. Body glabrous, fulvous, partially with black spots, without metallic reflexion and not covered by scales or hairs, broadly-ovate with prothorax at the base narrower than elytra (Figs 1-3). Head hypognathous, partially retracted into the prothorax, without wide ocular grooves but with narrow grooves which are situated along the upper part of inner edges of the eyes (Fig. 4). "Frontoclypeus" trapeziform, not separated from the frons, and ocular grooves are not connected with its lateral margins. Eyes comparatively small, their upper edge situated in the middle of the head height, notched on middle of the inner edge. Antennae filiform, with $5-11^{\text {th }}$ segments slightly widened, but not flattened. In all known species of the genus color of antennae is flexen, lighter than other parts of the body excluding tarsi. Prothorax with margined, rounded lateral sides, not reaching sligtnly the fore edge; anterior margin of "propleurae" is convex, getting slightly to upper part of prothorax. Anterolateral setae are placed almost on its anterior edge, slightly below the line of the lateral margins of prothorax. Hypopleural suture not reaches the lateral margin of pronotum as good suture. Antennal grooves are developed; anterior edge of prosternum is narrowly bent downwards; intercoxal prosternal projection is wide, in narrowest place equal in wide to fore coxa (Fig. 5). Mesosternum almost as wide as prosternal projection. Metaventrite is as long as prosternum. Abdominal tergites in grown rigid beetles are very strong. Pygidium without longitudinal groove (Fig. 6). $5^{\text {th }}$ ventrite with or without transverse row of setae on the inner surface (Figs 78) Ovipositor (Fig. 9) is complete but short, without styli, with whole transverse $8^{\text {th }}$ tergite and ventrite, looking like tignum. Paraprocts are fused with apodemes of proctiger and 

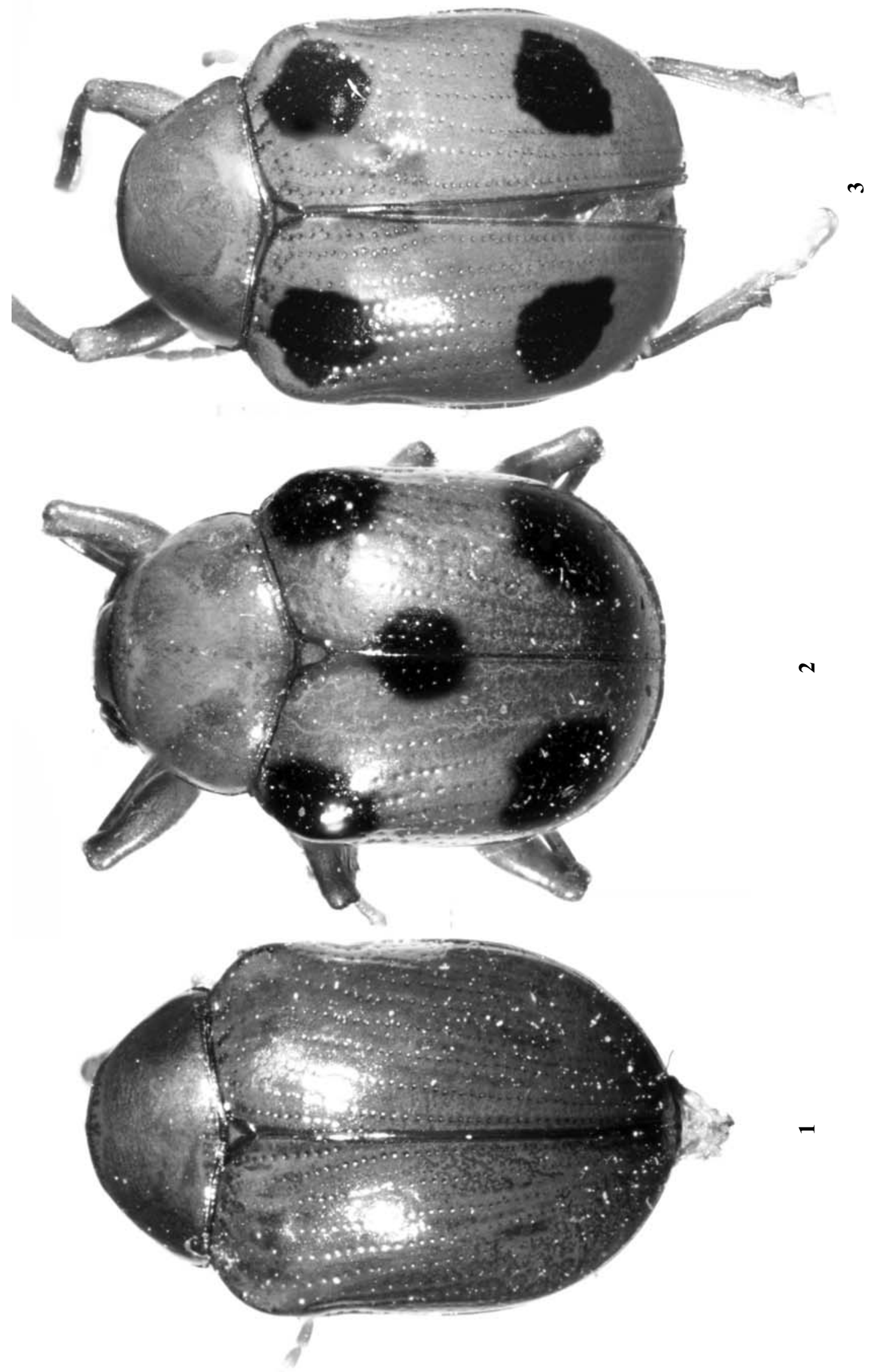

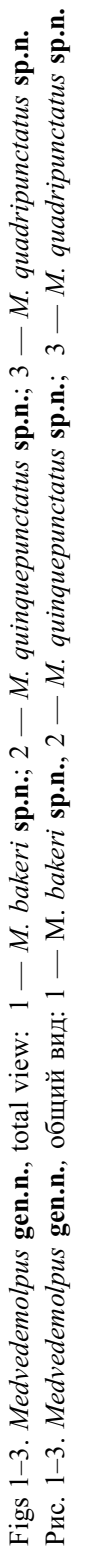




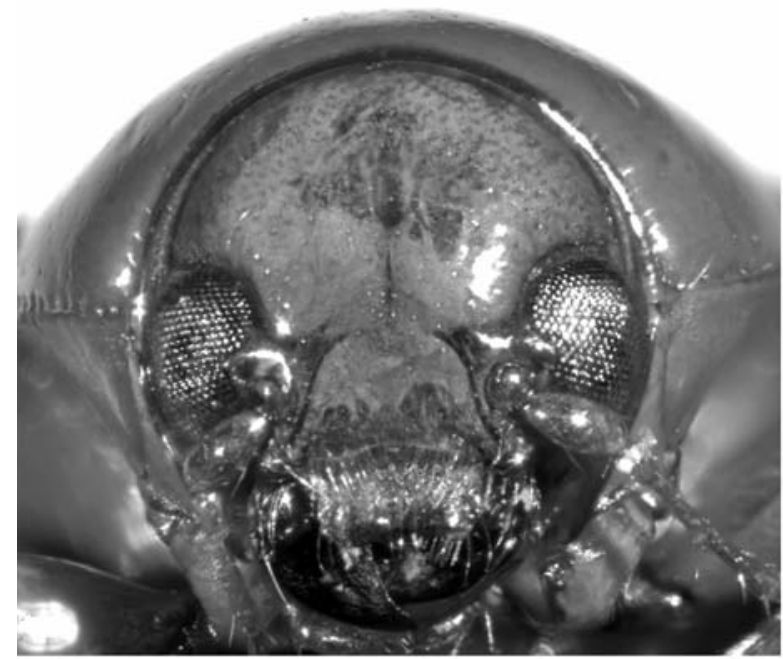

4

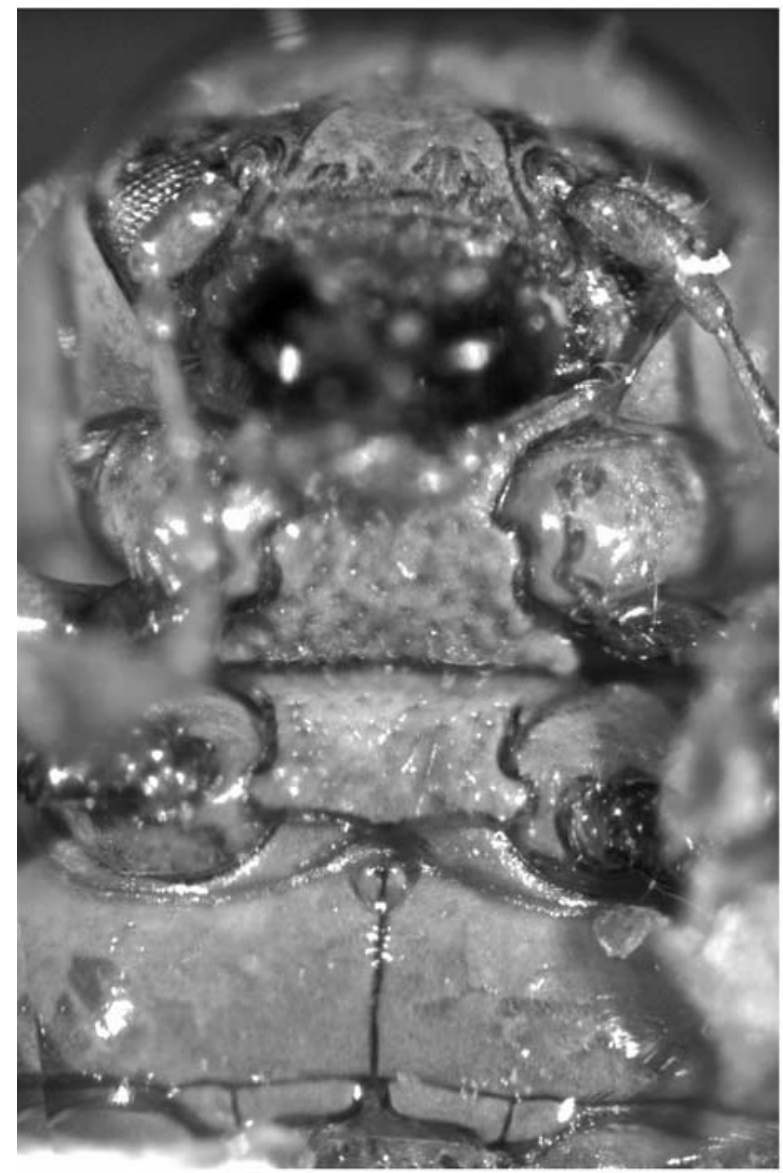

5
6

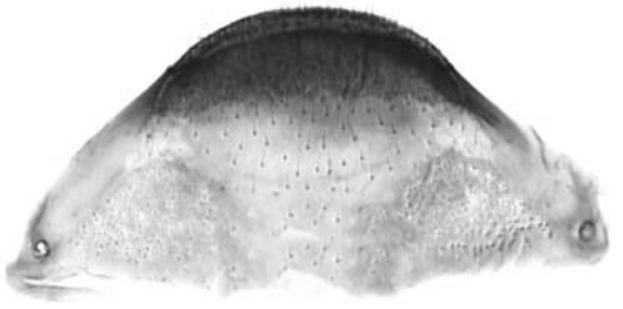

7

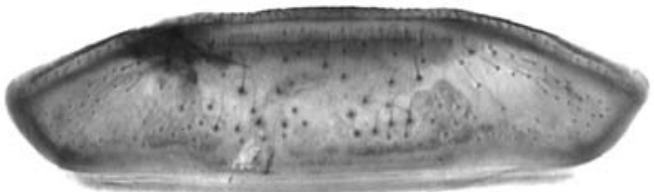

8
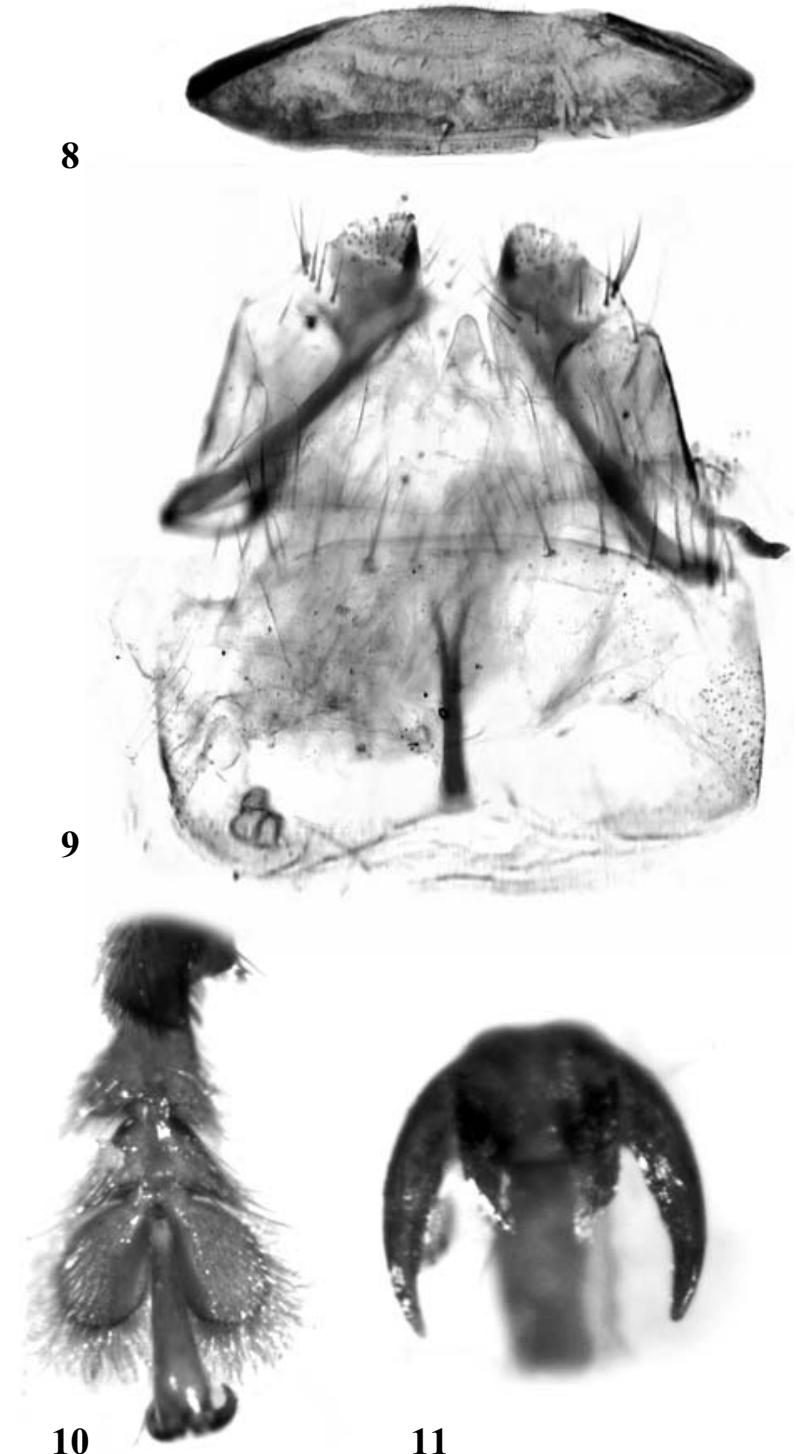

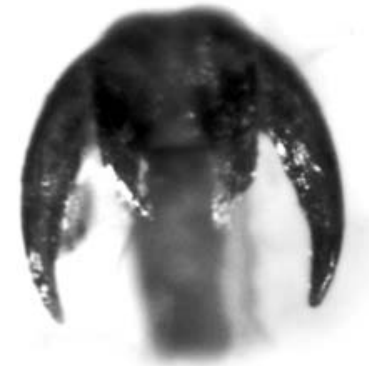

11

Figs 4-11. Medvedemolpus spp.: 4-5 - M. basilianus sp.n.; 6-7, 9-11-M. quadripunctatus sp.n.; 8 - M. bakeri sp.n.; 4 - head; 5 - thorax; 6 - pygidium; 7-8 - $5^{\text {th }}$ ventrite; 9 - ovipositor; 10 - middle tarsus; 11 - claws; 4 - anterior view; 5 - ventral view. Рис. 4-11. Medvedemolpus spp.: 4-5 - M. basilianus sp.n.; 6-7, 9-11-M. quadripunctatus sp.n.; 8 - M. bakeri sp.n.; 4 - голова; 5 - грудь; 6 - пигидий; 7-8 - 5 вентрит; 9 - яйцеклад; 10 - средняя лапка; 11 - коготки; 4 - спереди; 5 - снизу. 


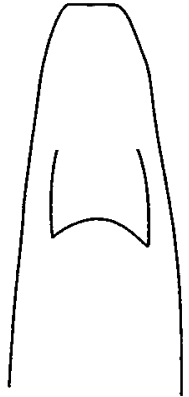

12

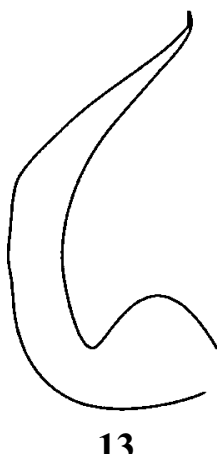

13

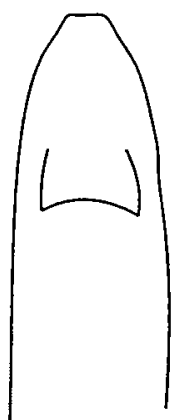

14

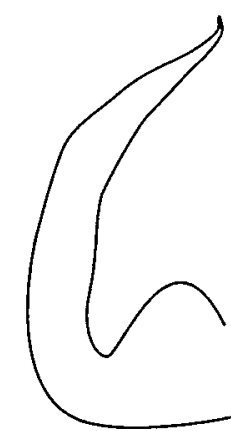

15

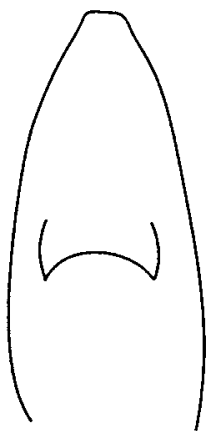

16

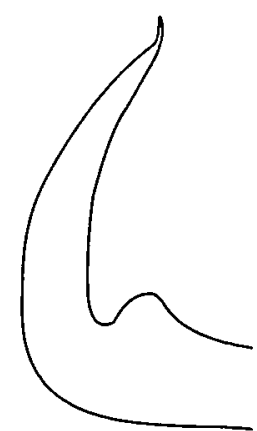

17

Figs 12-17. Aedeagus of Medvedemolpus spp.: 12-13 - M. quinquepunctatus sp.n.; 14-15 - M. basilianus sp.n.; 16-17 - M. bakeri sp.n.; 12, 14, 16 - dorsal view; 13, 15, 17 - lateral view.

Рис. 12-17. Эдеагус Medvedemolpus spp.: 12-13 - M. quinquepunctatus sp.n.; 14-15 - M. basilianus sp.n.; 16-17 - M. bakeri sp.n.; 12, 14, 16 - сверху; 13, 15, 17 - сбоку.

valvifers. Elytra with developed humeral calli but without basal convexity; scheme of puncture rows is typical of Nodinini: generally 12 rows, $1^{\text {st }}$ is shortened, $2^{\text {nd }}-6^{\text {th }}$ are full, $7^{\text {th }}$ and $10^{\text {th }}$ are placed behind of humeral calli, $8^{\text {th }}$ and $9^{\text {th }}$ are shorter, partly confused and placed between previous, $11^{\text {th }}$ row is shortened, placed behind humeral calli and partly combined with $12^{\text {th }}$ behind the fore third of elytral length; $12^{\text {th }}$ row is full and margins the main part of elytra. Elytral edging is visible from above behind humeral calli and almost to the apex of elytra. Epipleurae are developed, glabrous, almost horizontal, converging to the apex of elytra but reaching it. Hind wings are developed. Legs with widened fore and hind femora and less widened middle femora. Hind femora with very small tooth below, middle femora with almost unvisible rudimentary tooth and fore femora without teeth. Middle and hind tibiae with excavation before apex, very developed in middle tibiae. Tarsi of all legs with widened $3^{\text {rd }}$ tarsomer, which is 1,5 times as wide as equal $1^{\text {st }}$ and $2^{\text {nd }}$ tarsomers (Fig. 10). Claws bifid, but with short inner lobes, that somewhat resembles appendiculate ones (Fig. 11).

DIAGNOSIS. Pygidium without longitudinal groove, puncturation of elytra arranged in 12 longitudinal rows, middle and hind tibiae excavated; inner edge of the eyes excavated; prothorax margined on sides. Propleurae convex; claws slightly bifid; middle femora with almost invisible, hind femora with very small tooth; head without wide ocular grooves; antennal segments not dilated; $3^{\text {rd }}$ tarsomer widened; elytra not dilated; sternites between fore and middle coxae as wide as coxa; ovipositor short.

ETYMOLOGY. The genus named after Dr. Lev $\mathrm{N}$. Medvedev, famous specialist on Chrysomelidae, to his $75^{\text {th }}$ anniversary. The name combined from parts of the surname Medvedev and of the name Eumolpus, which indicates the subfamily affiliation.

DISCUSSION. The genus belongs to the tribe Nodinini by the absence of longitudinal groove on pygidium, puncturation of elytra arranged in 12 longitudinal rows and excavated middle and hind tibiae. Its belonging to the section Typophorites which is defined by convex propleurae, excavated inner edge of the eyes and bifid claws. In this section, genus Medvedemolpus gen.n. differs from most of the genera by body shape with well-developed humeral calli, pronotum narrower than elytra and absence of wide ocular grooves. It is close to the genus Mouhotina, which contains several species, but of these species completely corresponds to the generic characters only the type species from Cambodia, which differ from new genus by flattened segments of antennae and appendiculate claws. Neotropical genus Typophorus differs by wide ocular grooves and narrower intercoxal projections. The Oriental genus Cleoporus Lefèvre, 1884, differs by wide ocular grooves, narrower intercoxal projections and more elongate body shape. There are no more similar species as to habitus or as to combination of characters within numerous African genera of the section.

\section{Medvedemolpus bakeri Moseyko, sp.n.} Figs 1, 8, 16-17

MATERIAL. Holotype, $\sigma^{\gamma}$, "Surigao. Mindanao. Baker" (USNM). Paratypes: $1 \sigma^{7}$ (ZISP), 1 (USNM), same label as holotype.

DESCRIPTION. Body yellow to reddish-brown, without elytral pattern (Fig. 1). Antennae and tarsi yellow. Head and pronotum glabrous, pronotum almost impunctate. Antennae with widened $6^{\text {th }}-11^{\text {th }}$ segments. Pronotum 1.6 times as wide as long, with maximal width in front of the base. Elytra almost 2.5 times longer than pronotum, with regular rows of punctures (only $8^{\text {th }}-9^{\text {th }}$ rows are confused). Pygidium with transverse line (bent), parallel to back edge; $5^{\text {th }}$ ventrite of female without transverse line of setae on the inner membrane (Fig. 8). Aedeagus with comparatively narrow apex (Fig. 16-17). Spermatheca comparatively thick, with apex not bent (Fig. 18).

Body length 4.7-4.9 mm; width 3.0-3.2 mm.

DIAGNOSIS. Body reddish-brown, without pattern on elytron. Aedeagus with comparatively narrow apex; 5th ventrite of female without transverse row of setae.

DISTRIBUTION: Philippines: North Mindanao, Surigao del Norte prov. Surigao.

ETYMOLOGY. The species named after C.F. Baker, collector of Philippinese insects.

\section{Medvedemolpus quinquepunctatus Moseyko, sp.n.} Figs 2, 12-13

MATERIAL. Holotype, ऽ', "Zamboanga. Mindanao. Baker" [USNM]. Paratype, + , Philippines, Mindanao, S. Cotabato Prov., Manobo Tasaday Forest Reserve, Mt. Tasaday, 3.II.-10.III.1991, leg. P. Lays (cLM).

DESCRIPTION. Body reddish, with 5 black spots: 2 spot on each elytron, on the humeral callus and near apex, and common spot on both elytra behind scutellum (Fig. 2). Antennae and tarsi yellow. Head and pronotum glabrous, pronotum almost impunctate. Antennae with widened $6^{\text {th }}-11^{\text {th }}$ seg- 


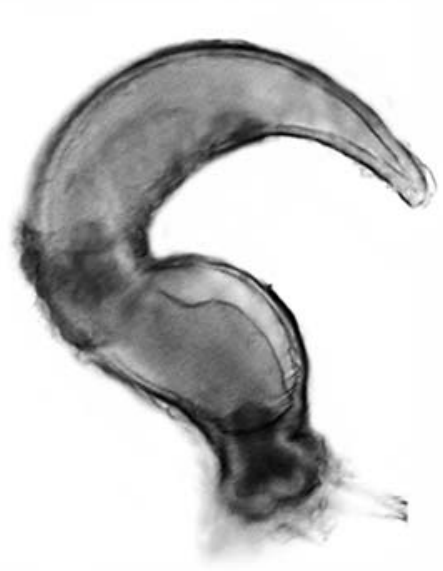

18

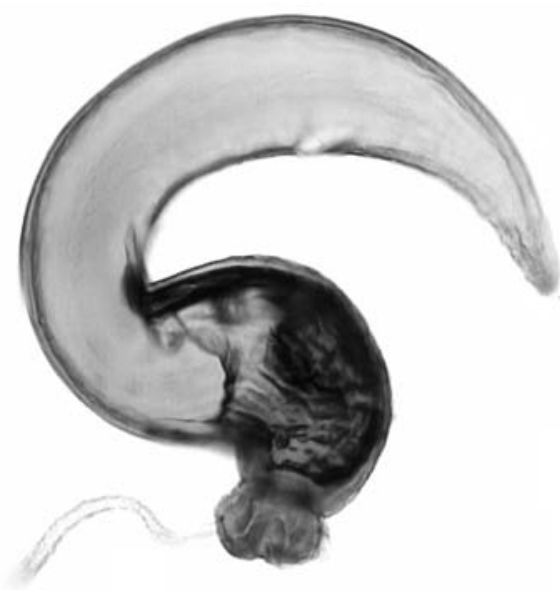

19

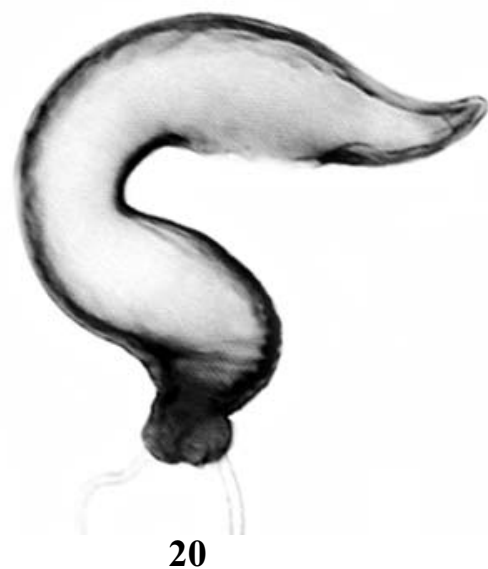

20

Figs 18-20. Spermatheca of Medvedemolpus spp.: 18 - M. bakeri sp.n.; 19 - M. quadripunctatus sp.n.; $20-$ M. spA.

Рис. 18-20. Сперматека Medvedemolpus spp.: 18 - M. bakeri sp.n.; 19 - M. quadripunctatus sp.n.; $20-M$. spA.

ments. Pronotum 1.5 times as wide as long, with maximal width in front of the base. Elytra 2.2 times longer than pronotum, with regular rows of punctures (only $8^{\text {th }}-9^{\text {th }}$ rows are confused). Pygidium with transverse line (bent), parallel to back edge. Aedeagus with wide spatulate apex, 2 times narrower than aedeagus in middle part (Figs 12-13).

Body length 5.0-5.8 mm; width of male $3.2 \mathrm{~mm}$.

DIAGNOSIS. Elytra comparatively short, 2.2 times longer than pronotum, with 5 black spots, two on each elytron and one common on suture. Aedeagus with wide spatulate apex.

DISTRIBUTION: Philippines: South Mindanao: South Cotabato and Zamboanga del Sur provinces.

\section{Medvedemolpus basilianus Moseyko, sp.n.} Figs 4-5, 14-15

MATERIAL. Holotype, O', "Island of Basilian. Baker" (USNM).

DESCRIPTION. Body yellow. Antennae and tarsi whitish-yellow. Head (Fig. 4) and pronotum glabrous, pronotum almost impunctate. Antennae with widened $6^{\text {th }}-11^{\text {th }}$ segments. Prosternum and mesosternum punctured (Fig. 5). Pronotum 1.5 times as wide as long, with maximal width in front of the base. Elytra 2.1 times as long as pronotum, with regular rows of punctures (only $8^{\text {th }}-9^{\text {th }}$ rows are confused). Pygidium with transverse line (bent), parallel to back edge. Aedeagus with truncated apex (Figs 13-15), narrower than the same in M. quinquepunctatus.

Body length $5.2 \mathrm{~mm}$; width $3.3 \mathrm{~mm}$.

DIAGNOSIS. Elytra comparatively short, 2.1 times longer than pronotum, without black pattern. Aedeagus with truncated apex.

DISTRIBUTION: Philippines: Basilian Island.

Medvedemolpus quadripunctatus Moseyko, sp.n. Figs 3, 6-7, 9-11, 19

MATERIAL. Holotype, + , “Mt. Makiling Laguna, P.I. IV. II. 31. F.C. Hadden Collector" (USNM). Paratypes: 1 \% "Mt. Makiling. Luzon. Baker" (USNM); 1 "Mt. Banahao. P.I. Baker" (ZISP).

DESCRIPTION. Larger than other species. Body reddish-brown, with 2 black spot on every elytra, near the humeral callus and near apex (Fig. 3), which can be small or absence. Antennae and tarsi (Fig. 10) yellow. Claws semibifid (Fig. 11). Head and pronotum glabrous, pronotum almost impunctate. Antennae with widened $6^{\text {th }}-11^{\text {th }}$ segments. Pronotum 1.5 times as wide as long, with maximal width in front of the base. Elytra 2.5 times longer than pronotum, with not perfectly regular rows of punctures, $8^{\text {th }}-9^{\text {th }}$ rows are completely confused. Pygidium (Fig. 6) with transverse line (bent), parallel to back edge; $5^{\text {th }}$ ventrite of female (Fig. 7) with transverse line of setae on the inner membrane parallel to apical edge. Ovipositor short (Fig. 9). Spermatheca comparatively thin, with apex not bent (Fig. 19).

Body length 7.5-7.6 mm; width 4.5-4.6 mm.

DIAGNOSIS. Elytra sometimes with 4 black spots. 5 th ventrite of female with transverse row of setae parallel to apical edge.

DISTRIBUTION. Philippines: Luzon.

\section{Medvedemolpus spA.}

Fig. 20

MATERIAL: 2 ㅇ, "Iligan. Philippines. Mindanao" (USNM).

Reddish-brown beetles, 5.9-6.7 $\mathrm{mm}$ in length, without elytral pattern.. Body shape is typical of the genus. $5^{\text {th }}$ ventrite with transverse row of setae. Spermatheca with apex bent upwards (Fig. 20). Probably, these specimens are the females of M. quinquepunctatus, sp.n.

\section{Medvedemolpus spB.}

MATERIAL: $1 \uparrow$ “Cuernos Mts., Negros, Baker” (USNM).

Reddish-brown, $6.9 \mathrm{~mm}$ in length, without elytral pattern. Body shape is typical for the genus. $5^{\text {th }}$ ventrite without transverse row of setae. Spermatheca with apex not bent.

\section{A KEY TO THE SPECIES OF MEDVEDEMOLPUS GEN.N.}

1(6). Body longer than $5.8 \mathrm{~mm}$.

2(3). Species from Luzon. Elytral pattern (if present) consists of 4 black spots ( 2 on every elytron). Body large, 7.5-7.6 $\mathrm{mm}$ in length. Spermatheca with not deflected apex; $5^{\text {th }}$ ventrite with transverse inner row of setae M. quadripunctatus sp.n.

3(2). Species from other islands. Elytra without pattern. Body shorter than $7 \mathrm{~mm}$.

4(5). Spermatheca with apex bent upwards; $5^{\text {th }}$ ventrite with transverse inner row of setae; body length $5.9-6.7 \mathrm{~mm}$. Mindanao: Iligan..... 
5(4). Spermatheca with apex not bent. $5^{\text {th }}$ ventrite without transverse inner row of setae; body length $6.9 \mathrm{~mm}$. Negros M. $\mathrm{spB}$.

6(1). Body shorter than $5.9 \mathrm{~mm}$. Species from Mindanao and Basilian.

7(8). Aedeagus with narrow apex. Elytra without pattern. North Mindanao: Surigao .... M. bakeri sp.n.

8(7). Aedeagus with wide truncated apex.

9(10). Aedeagus with apex about 2 times narrower than its middle part. Elytra with 5 black spots ( 2 on every elytron and 1 on suture behind scutellum). South Mindanao .... .M. quinquepunctatus sp.n.

10(9). Aedeagus with apex about 3 times narrower than its middle part. Coloration without black spots. Basilian .. M. basilianus sp.n.

A key to the genera of the tribe Nodinini of Philippines.

1(8). Claws appendiculate. Basal convexity on elytra usually developed.

2(3). Propleurae convex. Head without wide ocular grooves Cleorina Lefèvre, 1885

3(2). Propleurae straight or concave.

4(5). Body ovate. Elytra slightly dilated Phaedroides Lefèvre, 1885

5(4). Body not ovate; elytra with well developed humeral calli.

6(7). Head without wide ocular grooves; if narrow grooves are present, they are parallel to inner edge of the eyes Basilepta Baly, 1860

7(6). Head with more or less wide ocular grooves, inner edge of which is not parallel to inner edge of the eyes Pagria Lefèvre, 1884

8(1). Claws bifid or semibifid with shortened inner lobes. Basal convexity on elytra often absent.

9(10). Fore femora widened more than others. Body elongate, large, often with metallic bands, sometimes pubescent. Propleurae straight .................. Chrysopida Baly, 1861

10(9). Fore femora widened just as or less than hind ones. Body never being pubescent.

11(20). Propleurae straight or concave.

12(13). Eyes cone-shaped. Body very elongate, with antennae longer than body length ........... Coniomma Weise, 1922
13(12). Eyes rounded, often with excavation on inner edge. Body not so elongate; antennae not longer than body.

14(15). Head with sulcate ocular grooves; elytra with ridges Pagellia Lefèvre, 1885

15(14). Head without ocular grooves or with narrow ones without sulcus and parallel to eyes edge.

16(17). Clypeus with wide right-angeled excavation. Pronotum with wide margin; eyes without excavation on inner edge Clypeolaria Lefèvre, 1885

17(16). Clypeus without wide excavation. Eyes excavated on inner edge.

18(19). Prosternum wide. Pronotum more narrow behind than in front. All femora with tooth. Very close to next genus Lindinia Lefèvre, 1893

19(18). Prosternum narrower. Pronotum narrower in front

0(11). Propleurae convex.

Rhyparida Baly, 1861

21(22). Elytra of male with hump, strongly dilated around. Elytra of females are also dilated but less than in males. Hypopleural suture is deep. Longer than $5 \mathrm{~mm}$....

Phytorellus Medvedev \& Moseyko, 2003

22(21). Elytra without hump, if they are dilated, the hypopleural suture is not so deep.

23(24). Elytra of male are dilated. Body ovate, humeral calli less developed. Pronotum are almost as wide as elytra on the base. Phytorus Jacoby, 1884

25(24). Elytra not dilated, sides of elytra are vertical. Pronotum narrower than elytra.

26(27). Head with wide ocular grooves, or at least ocular grooves with sulcus above eyes. Body more elongate. Ovipositor longer ................... Cleoporus Lefèvre, 1884

27(26). Head with narrow ocular grooves parallel to eyes edge and not sulcate. Ovipositor short

Medvedemolpus gen.n.

\section{References}

Seeno T.N. \& Wilcox J.A. 1982. Leaf beetle genera (Coleoptera: Chrysomelidae) // Entomography. Vol.1. P.1-221. 